BACTERIOLOGICAL NOMENCLATURE A N D

T A XONOMY

Volume 3

June 1, 1953

Numbers 2 and 3

\title{
NEWS AND NOTICES
}

SYNOPSIS. This double issue of the BULLETIN replaces the April and July issues. It includes the provisional agenda of the International Committee on Bacteriological Nomenclature, of the Judicial Commission, and of the several Taxonomic Subcommittees, all proposals for the emendation of the Bacteriological Code of Nomenclature, all OPINIONS subject to review, all requests for OPINIONS, various Committee Reports, and supporting documents.

Copies of this synopsis have been mailed to all members of International Committee on Bacteriological Nomenclature, to members of the Judicial Commission, and to members of the Taxonomic Subcommittees.

All members of these Committees are urged to consider carefully all proposals and their supporting documents in preparation for the meetings to be held in Rome under the auspices of the 6th International Congress for Microbiology, September 6-12, 1953 .

Committee and Commission Members who will be unable to attend the meetings in Rome are urged to assist in the appointment of their alternates who may act for them, and to send the names of such alternates to one of the Permanent Secretaries, Dr. Cowan or Prof. Wikén. 